\section{Zuriah}

Jurnal Pendidikan Anak Usia Dini
Volume 1, Nomor 2, 2020

ISSN 2746-0797 (p), 2746-0800 (e)

http://journal.iaincurup.ac.id/index.php/paud

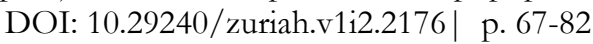

\title{
Manajemen Pembelajaran Dalam Mengembangkan Kemandirian Anak Usia Dini di TK Edelweis Kelurahan Tanjung Pinang Kecamatan Jambi Timur Kota Jambi
}

\author{
Siti Marwah \\ STAI Ma'arif Jambi, Indonesia \\ sitimarwah859@gmail.com
}

\begin{abstract}
This study aims to determine the Early Childhood Learning Strategy in the Development of Children's Independence in Edelweis Kindergarten, Jambi City. This research is based on the presence of children who are not yet independent in terms of the bathroom, children are still accompanied by parents in institutions until they return from school, children have not mingled with their peers. This research uses qualitative research techniques. The subjects of this study were children of group $B$ Edelweis Kindergarten Jambi City. As for the research subjects, all stakeholders of Edelweis Kindergarten Jambi City include the principal, teachers, and students. And the informant is the Edelweis Kindergarten Teacher in Jambi City. Data collection techniques using observation, documentation, and interviews. The instrument used in the observation was in the form of research sheets, for documentation using photos to document all children's activities during activities and interviews using interview guidelines with Group B teachers to find out the conditions and problems faced. The results of this study are 1. Early childhood learning strategies in the development of children's independence in Edelweis Kindergarten Jambi City using three steps, namely a). Planning b). Implementation and c) Evaluation. 2. Constraints faced in the application of PAUD learning in the development of children's independence in Edelweis Kindergarten, Jambi City are a) Lack of supporting infrastructure in online learning activities, b), lack of parental knowledge in caring for children's growth and development, and c) Lack of parental support for children's independence so that they will not feel confident in carrying out activities. 3. The results obtained from the implementation of the Strategy, PAUD learning in the development of children's independence is the application of early childhood learning strategies in developing children's independence in Edelweis Kindergarten, Jambi City, running well in accordance with the learning objectives that have been compiled together with the parents of students, even in the middle. In the middle of a semester the learning activities turned into an online system because during the pandemic, there was Covid 19.
\end{abstract}

Keywords: Management, Learning, Developing, Independence, Early childhood. 


\begin{abstract}
Abstrak
Penelitian ini bertujuan untuk mengetahui Streategi Pembelajaran PAUD dalam Pengembangan Kemandirian anak di TK Edelweis Kota Jambi. Penelitian ini di latar belakangi dengan adanya anak masih tampak belum mandiri dalam hal kekamar mandi, anak masib di temani oleh orang tua di lembaga bingga pulang sekolah, Anak-anak belum berbaur dengan sesama temanya. Penelitian ini menggunakan teknil penelitian kualitatif. Subjek penelitian ini anak kelompok B TK Edelweis Kota Jambi. Adapun yang menjadi subjek peneliti adalah semua stake bolder TK Edelweis Kota Jambi yang meliputi kepala sekolah, guru, dan Siswa. Dan yang menjadi informannya adalah Guru TK Edelweis Kota Jambi. Teknik pengumpulan data menggunakan observasi, dokumentasi, dan wawancara. Instrumen yang digunakan dalam observasi berupa lembar penelitisn, untuk dokumentasi menggunakan foto untuk mendokumentasikan segala aktivitas anak. selam kegiatan dan wawancara menggunakan pedoman wawancara dengan guru Kelompok B untuk mengetahui kondisi dan permasalahan yang dihadapi. Hasil Penelitian ini adalah 1. Strategi Pembelajaran PAUD dalam pengembangan Kemandirian Anak di TK Edelweis Kota Jambi dengan menggunakan tiga langkah yaitu a). Perencanan b). Pelaksanaan dan c) Evalusi. 2. Kendala yang di hadapi dalam penerapan Pembelajaran PAUD dalam pengembangan kemandirian anak di TK Edelweis Kota jambi adalah a. Minimnya sarana parasarana pendukung dalam kegiatan pembelajaran online, b), Minimnya pengetabuan orang tua dalam pengasuhan terhadap pertumbuhan serta pekembangan anak.dan c) Kurangnya dukungan orang tua terhadap kemandirian anak sehingga akan merasa tidak percaya diri dalam melakukan kegiatan. 3. Hasil Yang di dapati dari penerapan Strategi Pe,belajaran PAUD dalam Pengembangan kemandirian anak adalah penerapan strategi pembelajaran PAUD dalam pengembangan kemandirian anak di TK Edelweis Kota Jambi berjalan dengan baik sesuai dengan tujuan pembelajaran yang telah disusun bersama dengan orang tua siswa, meski di tengah tengah semseter kegiatan pembelajaran berubah menjadi sistem online dikarena dalam masa pandemi menghadapi Covid 19.
\end{abstract}

Kata Kunci: manajemen, pembelajaran, mengembangkan, kemandirian, anak usia dini.

\title{
A. PENDAHULUAN
}

Usia lahir sampai memasuki pendidikan dasar merupakan masa keemasan sekaligus masa kritis pada tahap kehidupan yang akan menentukan perkembangan anak selanjutnya. Masa ini merupakan masa yang tepat untuk meletakkan dasar-dasar pengembangan yang dimiliki anak (Mansur, 2009: 18). Seorang anak manusia yang dilahirkan ke dunia ini sudah dibekali dengan pembawaan, bakat atau potensi yang sangat penting dalam proses perkembangan berikutnya. Namun demikian lingkungan yang berbeda disekitar anak yang dibesarkan, termasuk dalam hal ini lingkungan pendidikan juga turut memberikan andil dan pengaruh dalam perkembangan anak. 
Lingkungan perlu dirancang sedemikian rupa agar dapat mengembangkan dan menyempurnakan apa yang dibawa anak sejak lahir. Rancangan itu dapat dilakukan di rumah, sekolah,atau dimana saja. Di sekolah yaitu TK (Taman kanak-kanak), RA (Raudhatul Athfal), atau KB (Kelompok Bermain), rancangan itu sebagai rancangan pembelajaran atau pelaksanaan program. Sebagaimana di atur dalam undang-undang Nomor 20 Tahun 2003 pasal 28 menyatakan bahwa "Pendidikan anak usia dini pada jalur pendidikan formal berbentuk Taman Kanak-kanak (TK), Raudhatul Athfal (RA), atau bentuk lain yang sederajat". Pada lembaga penddikan Taman Kanak-kanak (TK) menyelenggarakan pendidikan untuk mengembangkan kepribadian dan potensi diri sesuai dengan tahap perkembangan peserta didik.

Pendidikan Anak Usia Dini (PAUD) dilaksanakan dengan tujuan untuk membentuk anak Indonesia yang berkualitas dan diharapkan anak akan tumbuh dan berkembang sesuai dengan tingkat perkembangannya sehingga memiliki kesiapan yang optimal dalam memasuki pendidikan dasar serta mengarungi kehidupan di masa dewasa.

Selain dilingkungan keluarga, pengembangan kemandirian anak juga dapat dilakukan di sekolah. Dalam hal ini guru sebagai subjek utama harus mampu mengelola kegiatan pembelajaran dengan baik, mulai dari tahap perencanaan, pelaksanaan, serta tahap evaluasinya. Selain itu juga guru dapat memberikan bimbingan dalam rangka membantu anak memahami alasan tentang diterapkannya aturan seperti keharusan memlihara ketertiban didalam kelas, larangan masuk keluar kelas dengan saling mendahului, membantu mereka untuk memelihara persahabatan, kerjasama, saling membantu dan saliung menghormati.

Berdasarkan hasil gran tour awal oleh peneliti pada tanggal 20 Maret 2020 di lembaga pendidikan Anak usia dini TK Edelweis Kota jambi, menemukan beberapa hal yakni:

1. Anak masih tampak belum mandiri dalam hal kekamar mandi.

2. Anak masih di temani oleh orang tua di lembaga hingga pulang sekolah.

3. Anak-anak belum berbaur dengan sesama temanya .

4. Anak-anak masih enggan beranjak saat mengikuti kegiatan bermain.

Dari beberapa contoh di atas, perlu adanya upaya pengembangan kemampuan anak dalam kemandirian. Melalui manajemen pembelajaran, kemampuan kemandirian anak dapat dikembangkan dengan berbagai 
materi yang telah dikembangkan guru. Berdasarkan latar belakang di atas, penulis tertarik untuk melakukan penelitian tentang "Manajemen Pembelajaran Dalam Mengembangkan kemandirian Anak Usia Dini di TK Edelweis Kelurahan Tanjung Pinang kecamatan jambi Timur Kota jambi".

\section{B. METODE PENELITIAN}

Penelitian ini berlokasi di TK EdelweisKelurahan Tanjung Pinang Kecamatan Jambi Timur Kota Jambi.Penelitian ini berbentuk kualitatif. Metode dalam suatu penelitian ini adalah metode deskriptif kualitatif (Prosedur penelitian yang menghasilkan data deskriptif berupa kata-kata tertulis atau lisan dari orang-orang dan perilaku yang dapat diamati). Data primer dalam penelitian ini informasi dari pihak pertama yang menanggapi tentang Manajemen Pembelajaran dalam Pengembangan Kemandirian Anak di TK EdelweisKelurahan Tanjung Pinang Kecamatan Jambi TimurKota jambi. Data sekunder dalam penelitian ini histories dan geografis TK EdelweisKelurahan Tanjung Pinang Kecamatan Jambi TimurKota Jambi tersebut. Struktur Organisasinya, sarana dan prasarana yg dimiliki. subjek peneliti adalah semua stake holder TK EdelweisKelurahan Tanjung Pinang Kecamatan Jambi TimurKota Jambi yang meliputi kepala sekolah, guru, dan Siswa. Dan yang menjadi key informannya adalah Guru TK Edelweis Kota Jambi. Sedangkan yang lainnya seperti kepala sekolah adalah informan tambahan.Adapun teknik pengambilan sampel menggunakan purposive sampling. "Tehnik purposive sampling adalah teknik pengambilan sampel sumber data dengan pertimbangan tertentu yang dianggap paling mengetahui tentang yang akan diteliti. Teknik pengumpulan data terdiri dari wawancara, observasi, dan dokumentasi.

\section{HASIL DAN PEMBAHASAN}

1. Perencanana merupakan suatu plan yang wajib di siapkan oleh guru terutama guru kelas.

Lembaga TK Edelweis sebelum saat tahun ajaran baru guru menyusun program pembeajaran dalam jangka panjang dan jangka pendek. Dan khusus untuk pengembangan kemandirian anak ini tercantum dalam RPPH yang disusun sehari sebelum melaksanakan kegiatan pembelajaran. Berdasarkan hasil wawancara kepada guru 
kelas B TK Edelweis Kota jambi:“Untuk Pembelajaran yang akan dilakasanakan dalam kegiatan keesokan harinya maka kami sebagai guru kelas menyiapkan rencana kegiatan yang berbentuk RPPH disana semua tersusun mulai dari kegiatan pesiapan sampai pada kegaiatan evaluasi dari kegiatan pada hari itu". Lebih lanjut hasil wawancara penulis yang didapat dari guru kelas TK B Edelweis mengungkapkan, beliau mengungkapkan bahwa; "Untuk perencanaan kegiatan pengembangan kemandirian anak kami guru menyiapkan kegiatan yang di kemas dalam satu kegiatan seperti bermain balok, dalam anak bermain balok anak melakukan kegiatan dengan sendiri tanpa harus terus dibantu dalam bermain". Dari wawancara diatas dapat penulis pahami bahwa dalam perencanan pengembangan kemandirian anak di TK B Edelweis Kota Jambi menunjukkan adanya kesiapan dari guru kelas untuk melaksanakan kegiatan dengan baik dan benar hal ini di buktikan dengan adanya RPPH yang telas di siapkan dalam bentuk dokumen sebagaimana terlampir di akhir halaman skripsi penulis.

Dalam proses penyusunan perencanaan pembelajaran harian sendiri para guru berpedoman kepada kurikulum yang ada di lembaga tersebut, yang mana di dalam penyusunan pembelajaran sendiri juga harus memperhatikan bagaimana memenuhi kebutuhan anak agar tercapai terhadap perkembangan yang diharapkan. Hal ini sebagaimana yang disampaikan oleh kepala lembaga TK Edelweis Kota Jambi dalam wawancara dengan beliau, mengungkapkan bahwa; "Dalam menyusun Rencana Pelaksanaan Pembelajaran Harian (RPPH), para guru di lembaga TK B Edelweis Kota Jambi ini berpedoman kepada kurikulum k-13, dimana perencanaan pelaksanaan pembelajaran harian di susun sebelum kegiatan di mulai. Biasanya perencanaan disusun satu minggu sebelum kegiatan dilaksanakan. Dalam perencanaan pelaksanaan pembelajaran harian para guru mengembangkan kegiatan perencanaan berdasarkan Rencana Pelaksanaan Pembelajaran Mingguan (RPPM), sedangkan RPPM sendiri juga di kembangkan berdasarkan Program Semester. Dimana dalam setiap semester terdapat Sub-sub Tema yang harus dikembangkan dan menjadi pembelajaran yang harus disampaikan kepada peserta didik agar setiap perkembangan peserta didik dapat tercapai dengan baik". 
Dalam proses perencanaan pelaksanaan pembelajaran tentunya harus memperhatikan aspek-aspek perkembangan pada anak usia dini, dimana terdapat enam aspek perkembangan yaitu; Aspek Nilai Moral dan Agama (NAM), Aspek Kognitif, Aspek Bahasa, Aspek Sosial Emosional (Sosem), Aspek Fisik Motorik, dan Aspek Seni. Dan juga dalam menyusun perencanaan pelaksanaan pembelajaran harian tentunya tidak lepas dari kebutuhan perkembangan setiap peserta didik, dimana dalam setiap pembelajaran harus mencakup tentangpendekatan saintifik yang tercantum dalam kurikulum 2013 PAUD, yaitu; suatu proses pembelajaran yang dirancang sedemikian rupa agar peserta didik secara aktif membangun kompetensi sikap, pengetahuan, dan keterampilan melalui tahapan mengamati, menanya, mengumpulkan informasi, menalar, dan mengomunikasikan. Hal ini sebagaimana wawancara penulis kepada guru kelas TK lembaga TK Edelweis Kota Jambi; "Dalam proses membuat perencanaan pelaksanaan pembelajaran bagi peserta didik di TK Edelweis Kota Jambi ini, tentunya para guru juga memperhatikan apa-apa yang harus diperhatikan dalam setiap pelaksanaan pembelajaran yang akan dilakukan.

Tentunya berpedoman kepada Kurikulum 2013 yang mana aspek-aspek yang harus dikembangkan yaitu meliputi Aspek Nilai Moral dan Agama (NAM), Aspek Kognitif, Aspek Bahasa, Aspek Sosial Emosional (Sosem), Aspek Fisik Motorik, dan Aspek Seni dan juga kegiatan perencanaan yang dilakukan juga tidak lepas dari perencanaan pembelajaran saintifik yaitu dimana para peserta didik secara aktif membangun kompetensi sikap, pengetahuan, dan keterampilan melalui tahapan mengamati, menanya, mengumpulkan informasi, menalar, dan mengomunikasikan". Berdasarkan hasil wawancara serta dokumen hasil observasi yang didapat oleh penulis mengenai perencanaan pembelajaran dalam pengembangan kemandirian anak di TK B Edelweis Kota jambi dapat dipahami bahawa guru kelas B TK Edelweis Kota jambi telah melaksanakan tugas dan fungsinya sebagai guru dalam perencanaan pengembangan kemandirian anak di sekolah tersebut.

2. Pelaksanaan Manajemen Pembelajaran Dalam Pengembangan Kemandirian 
Anak Usia Dini di Kelas B TK Edelweis Kota Jambi. Dalam pelaksanaan manajemen pembelajaran tentu ini tidak lepas dari adanya suatu perencanaan pembelajaran yang telah disusun sebelumnya. Oleh karena itu dalam pelaksanaan manajemen pembelajaran dalam pengembangan kemandirian anak di TK EdelweisKota Jambi, khususnya pada kelas TK B ini dilaksanakan secara mandiri di rumah dengan di dampingi oleh orang tua siswa di rumah. Hal ini terjadi karena saat ini kita sedang berhadapan dengan wabah Covid 19 atau korona, sehingga bukan hanya Jambi akan tetapi seluruh dunia sedang berduka.

Berdasarkan hasil wawancara kepada guru kelas B TK Edelweis Kota Jambi mengenai pelaksanaan pembelajaran di TK Edelweis, ia mengungkapkan bahwa dalam pelaksanaan pembelajaran di lembaga TK edelweis ini, awalnya yang diterapkan di sekolah saat ini beralih ke rumah masing-masing, akan tetapi pelaksanan pengembangan kemandirian anak tetap dilaksanakan sesuai dengan perencanan pembelajaran yang telah disusun sebelumnya. Akan tetapi tempat beralih yang awalnya di sekolah menjadi di rumah masingmasing, hal ini dilakukan sebagai tindakan antisipasi sekolah terhadap penyebaran corona virus yang saat ini sedang melanda, dan juga merupakan bentuk kepatuhan kami terhadap aturan pemerintah.

Mengenai kebijakan yang dilakukan oleh sekolah TK Edelweis di paparkan oleh Kepala Sekolah TK Edelweis beliau mengungkapkan dalam wawacara penulis mengenai penerapan pelaksanaan kegiatan pembelajaran terutama dalam pengembangan kemandirian anak : "Sekolah mengikuti arahan pemerintah bahwa seluruh kegiatan pembelajaran semua di alihkan kerumah masingmasing, oleh sebab itu mengenai kegiatan pembelajaran yang telah disusun masih tetap sama akan tetapi bedanya hanya terletak pada tempat dan yang biasanya di dampingi oleh guru kelas masing masing akan tetapi sakarang kita menghadapi kondisi pandemi maka pelaksanan pembelajaran kita minta kerjasama orang tua untuk mendapingi ananda dirumah".

3. Evaluasi Penerapan ManajemenPembelajaran Dalam Pengembangan Kemandirian Anak usia Dini di TK Edelweis kota Jambi.

Untuk evaluasi ini merupakan suatu hal yang sangat penting dari suatu pelaksanaan kegiatan dimana evaluasi adalah sebagai alat 
ukur dari ketercapaian tujuan pembelajaran yang di inginkan dan sebagai bahan pertimbangan untuk kegiatan pembelajaran selanjutnya. Berdasarkan Hasil wawancara kepada guru kelas B TK Edelweis Kota Jambi mengenai evaluasi kegiatan penerapan manajemen pengembangan kemandirian anak pada kelas B TK Edelweis Kota Jambi, beliau mengungkapkan: "Dalam evaluasi kegiatan tetap sama kita lakukan, dan kita guru kelas menunggu laporan langsung dari orang tua siswa yang disampaikan secara daring dengan menggunakan group Whtassapp sesuai dengan waktu yang telah ditentukan".

Dokumen yang di tunjukan oleh guru mengenai evaluasi manajemen pelaksanan pembelajaran dalam pengembangan kemandirian ada di Kelas B TK Edelweis Kota Jambi, selanjutnya dijadikan dalam bentuk laporan portopolio hal ini di dokumentasikan oleh peneliti didalam lampiran skripsi ini.

Menurut guru kelas B TK Edelweismengenai hasil laporan dalam portopolio ini guru kelas mengungkapkan bahwa memang agak sedikit berbeda karena kita tidak dapat melihat secara lansung bagaimana proses peserata didik kita dalam melakukan kegiatan. Karna sepenuhnya di percayakan kepada orang tua dalam mendampingi putra putri mereka di rumah. Selain menggunakan portopolio sebagai bentuk dari hasil penilaian anak, para guru juga menggunakan penilaian berbentuk penilaian harian. Yang mana didalam penilaian harian ini merujuk kepada lembar RPPH (Rencana Pelaksnaan Pembelajaran Harian). Di dalam penilaian harian ini, para guru menggunakan penilaian ceklis, yang mana penilaian itu sendiri merujuk kepada kurikulum yang digunakan oleh Lembaga TK Edelweis Kota Jambi. Lembar penilaian ceklis harian ini berisi tentang materi yang masuk dalam kegiatan dan juga hasil dari kegiatan yang telah dilakukan oleh masing-masing peserta didik. Didalam penilaian harian ini guru menggunakan penilain berupa ceklis penilaian, yang akan dijelaskan sebagai berikut:

$\mathrm{BB}=$ Belum Berkembang (Belum berkembang artinya, anak belum mampu melakukan kegiatan pembelajaran sama sekali) 
MB = Mulai Berkembang (Mulai berkembang artinya, anak sudah mampu melaksanakan kegiatan pembelajaran, namun masih butuh bantuan dari pendidik maupun orang tua)

$\mathrm{BSH}=$ Berkembang Sesuai Harapan (Anak mampu melakukan kegiatan pembelajaran tanpa bantuan dari pendidik maupun orang tua)

BSB = Berkembang Sangat Baik (Anak tidak hanya mampu melakukan kegiatan pembelajaran sendiri, namun mampu membantu teman didalam melakukan kegiatan pembelajaran).

Sedangkan untuk lebih jelasnya tentang bagaimana hasil dari penilaian setiap peserta didik, maka penulis lampirkan pada lampiran di skripsi ini. Di dalam manajemen pelaksanan pembelajaran dalam pengembangan kemandirian ada di Kelas B TK Edelweis Kota Jambi ini sendiri di temukan dengan hasil beberapa anak yang mengalami perubahan peningkatan sikap kemandirian anak. Hal ini di tandai dengan perubahan perilaku anak didalam melaksanakan kegiatan harian pembelajaran. Hal ini di ungkapkan guru kelas, saat wawancara penulis dengan beliau, mengungkapkan bahwa: "Para guru melakukan evaluasi kepada setiap peserta didik berdasarkan informasi yang diberikan oleh para orang tua, dari informasi tersebut maka didapatlah bagaimana hasilmanajemen pengembangan kemandirian anak di TK edelweis Kota Jambi, hasil menunjukkan bahwa anak-anak di Kelompok B dari jumlah peserta didik 15 orang, 2 peserta didik mampu mencapai penilaian dengan kategori penilaian BSB (Berkembang Sangat Baik). Hal ini ditandai dari perubahan sikap dan perilaku kemandirian anak didalam melakukan kegiatan pembelajaran dirumah, sedangkan 4 orang peserta didik mampu mencapai penilaian BSH (Berkembang Sesuai Harapan), dan 8 peserta didik mencapai penilaian MB (Mulai Berkembang), dan sisanya 1 peserta didik mencapai penilaian BB (Belum Berkembang)".

Berdasarkan hasil observasi dan wawancara penulis kepada guru kelas TK Edelweis Kota Jambi, maka didapatlah dua orang peserta didik yang mencapai penilaian BSB (Berkembang Sangat Baik) dalam pelaksanaan kemandirian anak. Oleh karena itu penulis mencoba untuk mewawancarai salah satu orang tua dari peserta didik yang mana penilaian nya mampu mencapai penilaian BSB 
(Berkembang Sangat Baik). Dari hasil observasi penulis disimpulkan bahwa terjadi perubahan tingkah laku dan sikap dalam berbagai macam aktifitas kegiatan pembelajaran selama dirumah, anak mampu melakukan kegiatan secara mandiri, dan mampu untuk memberikan motivasi kepada orang tua untuk menemani anak dalam setiap aktifitas kegiatan pembelajaran. Hal ini sebagai mana di ungkapkan oleh orang tua peserta didik di TK Edelweis Kota Jambi:

a. Kendala Yang Di Hadapi Guru Dalam Menerapkan Manajemen Pembelajaran Dalam Pengembangan Kemandirian Anak Usia Dini di TK Edelweis Kota Jambi.

1) Fasilitas Sarana Prasarana

Dalam meningkatkan kualitas output dari proses pembelajaran tidak terlepas dari adanya dukungan sarana prasarana yang mamadai. Terkait dengan kondisi pandemi saat ini maka fasilitas utama dalam mendukung prose kegiatan pengembangan kemandirian anak adalah fasilitas yang sesuai dengan kebutuhan anak. Menurut guru kelas B TK Edelweis Kota Jambi kendala yang dihadapi oleh guru dalam mengembangkan kemandirian anak adalah seharusnya di dukung oleh sarana seperti APE yang di gunakan serta prasarana seperti alat komunikasi yang baik seperti internet, dimana untuk melihat adanya perkembangan kemandirian anak itu tidak terlepas dari benda-benda yang ada disekelilingnya serta bagaimana ia menggunakan fasilias yang ada secara mandiri.

Lebih lanjut guru kelas mengungkapkan kendala yang menjadi penghambat dalam pengembangan kemadirian anak adalah sarana yang disiapkan oleh orang tua terkadang tidak sesuai dengan usia anak, sehingga anak-anak tidak didukung untuk menjadi mandiri. Karena semua serba dilayani oleh pendamping dirumah. Karena semua di bantu oleh pendampingnya sehingga anak tidak lagi menjadi percaya diri seperti memasang celana, kekamar mandi sendiri, serta melakukan kegiataan dalam mengerjakan portoppolio yang di berikan oleh guru selama tidak kesekolah. Berdasarkan hasil dokumentasi yang di dapati yang berupa hasil portopolio anakanak, yang dikerjakan selama masa pandemi, bayak hasil yang 
selesai akan tetapi masih dengan bantuan dan pertolongan orang tua bukan hasil dari kerja dan kemandirian anak. Berdaasarkan hasil wawancara dan dokumentasi yang di peroleh oleh peneliti mengenai kendala yang dihadapi oleh guru dalam pengembangan kemandirian anak di TK Edelweis Kota Jambi adalah dari sisi fasilitas dan sarana prasarana yang tidak mendukung dari perkembangan anak terutama dalam hal kemandirian anak.

2) Pemahaman Orang Tua Terhadap Tumbuh Kembang Anak Yang Minim.

Mengenai pemahaman orang tua terhadap perkembangan serta pertumbuhan anak pada usia dini terutama usia 5-6 tahun ini tentu ini merupakan masa-masa perkembangan besar bagi anak usia dini. Maka ini tidak lepas dari pengasuhan orang tua dimana pengasuhan orang tua juga harus di dasari dengan pengetahuan serta pemahaman yang baik mengenai pola asuh. Dengan pemahaman serta pengetahuan yang mumpuni bagi orang tua ini akan mendukung dari perkembangan anak. Menurut guru kelas dalam wawancara peneliti mengenai pemahaman orang tua terhadap tumbuh kembang anak, beliau mengungkapkan: "Untuk orang tua siswa TK Edelweis Kota Jambi masih sangat minim, meski sudah di berikan pendampingan melalui kegiatan parenting yang di lakukan di awal tahun ajaran baru, akan tetapi masi ada juga orang tua yang masih tidak memperhatikan pentingnya kehadiran orang tua dalam memberikan stimulus kepada anak, sebagian orang tua memahami bahawa cukup di antar kesekolah anak sudah bisa".

Lebih lanjut peneliti melakukan wawancara kepada guru kelas B TK Edelweis Mengenai pengasuhan orang tua dalam pengembangan kemandirian anak, guru mengungkapkan: "Tidak semua orang tua melakukan tugas sebagaimana mestinya apalagi seharusnya di masa pandemi anak dan orang tua akan semakin dekat, akan semakin banyak waktu untuk bersama dan memberikan stimulus terutama dalam pengembangan kemandirian anak". Ungkapan dari hasil

${ }^{1}$ Wawancara guru kelas TK Edelweis Kota Jambi, 13 Mei 2020. 
wawancara dengan guru kelas sebanding dengan hasil portopiolio yang di kirim kepada guru kelas menujukkan kerjasama antara orang tua yang tidak begitu terbangun dimana ini ditunjukkan bahawa anak-anak bayak yang tidak mengerjakan tugas dengan tuntas akan tetapi dikerjakan lansung oleh orang tua. Dari wawancara serta temuan dalam hasil dokumentasi oleh peneliti, ini menunjukkan bahawa pemahaman orang tua terhadap tumbuh kembang serta pengembangan kemandirian anak masih sangat minim.

3) Kurangnya Dukungan Orang Tua

Dukungan orang tua terhadap pertumbuhan dan perkembangan anak sangatlah berperan. Dimana keikut sertaan orang tua dalam memberikan stimulus sangat berpengaruh terhadap kemandirian serta rasa percaya dini anak usia dini. Dalam wawancara kepada guru kelas B TK Edelweis Kota Jambi mengenai dukungan orang tua terhadap pengembangan kemandirian anak. Beliau mengungkapkan dalam hal ini orang tua seharusnya mendukung penuh kegiatan dan mensuport dari pada kegiatan yang sudah kita susun dengan baik sejak awal ketika di awal tahun ajaran baru, akan tetapi orang tua yang memiliki keterbatasan waktu serta pengetahuan yang minim, menjadikan kegiatan pembelajaran tidak sejalan dengan apa yang diharapkan dalam tujuan pembelajaran yang ingin dicapai.

Lebih lanjut dalam wawancara mengenai dukungan orang tua terhadap kegiatan pembelajaran kususnya pengembangan kemandirian anak di rumah, kita tidak bisa pantau lansung, bagaimana anak melaksanakan kegiatannya, semata kita hanya menerima laporan bahawa anak melakukan kegiatan sudah sesuai dengan apa yang di perintahkan oleh kita guru kelasnya. ${ }^{2}$ Dari wawancara diatas dapat peneliti pahami bahwa seharusnya di masa pandemi ini orang tua memiliki waktu yang cukup banyak untuk bersama anak-anak di rumah, dan dengan cukupnya waktu bersama dengan anak-anak dirumah tentu ini seharusnya dapat menciptakan suasana serta

\footnotetext{
${ }^{2}$ Wawancara Guru Kelas B TK Edelwis 18 Mei 2020
} 
dukungan penuh terhadap pertumbuhan dan perkembangan terutama dalam hal kemandirian anak. Akan tetapi karna keterbatasan pengetahuan oleh sebagaian orang tua siswa menjadikan ketidak sepadanan tujuan pembelajaran dengan hasil yang di capai dalam hal kemandirian peserta didik di TK Edelweis Kota Jambi.

b. Hasil Penerapan Manajemen Pembelajaran Dalam Pengembangan Kemandirian Anak Usia Dini di TK Edelweis Kota Jambi.

Penerapan manajemen pembelajaran dalam pengembangan kemandirian anak usia dini di Kelas B TK Edelweis Kota Jambi telah terlaksana sesuai dengan tujuan yang telah di susun meski kegiatan dilaksanakan di rumah secara daring (on line), dikarenakan dalam kondisi masa pandemi. Berdasarkan hasil observasi dan wawancara penulis kepada guru kelas TK Edelweis Kota Jambi, maka didapatlah dua orang peserta didik yang mencapai penilaian BSB (Berkembang Sangat Baik) dalam pelaksanaan kemandirian anak. Oleh karena itu penulis mencoba untuk mewawancarai salah satu orang tua dari peserta didik yang mana penilaian nya mampu mencapai penilaian BSB (Berkembang Sangat Baik).

Dari hasil observasi penulis disimpulkan bahwa terjadi perubahan tingkah laku dan sikap dalam berbagai macam aktifitas kegiatan pembelajaran selama dirumah, anak mampu melakukan kegiatan secara mandiri, dan mampu untuk memberikan motivasi kepada orang tua untuk menemani anak dalam setiap aktifitas kegiatan pembelajaran. Hal ini sebagai mana di ungkapkan oleh orang tua peserta didik di TK Edelweis Kota Jambi: "Selama kegiatan belajar di rumah ini, hampir semua kegiatan ananda Irul lakukan dengan antusias dan semangat, saya selaku orang tua hanya mendampingi saja. Untuk kegiatan pembelajaran mampu dia kerjakan sendiri. Sangat terlihat perubahan perilaku ananda Irul yang mengalami banyak perubahan kemandiriannya dalam melakukan berbagai macam kegiatan".

Dari data wancara dan dokumentasi tersebut diatas, penulis dapat memahami bahwa hasil penerapan manajemen pembelajaran PAUD dalam pengembangan kemandirian anak dapat terlaksana meski kegiatan dilaksanakan secara daring (on line). Kegiatan memang tidak dapat dipantau secara lansung oleh 
guru, mengenai hasil penerapannya apakah betul-betul anak telah melakukan kegiatan secara mandiri atau tidak, akan tetapi secara tersturuktur tercapai sesuai dengan tujuan pembelajaran yang ingin di capai berdasarkan hasil portopolio yang telah dikirim oleh orang tua selama kegiatan di masa pandemi di rumah. Dimana laporan yang di sampaikan orang tua melalui vidio serta hasil yang di capai anak dalam hal kemandirian dalam arti lain adalah bagaimana anak belajar untuk mampu mensyukuri atas nikmat Tuhan, anak menggunakan kata sopan pada saat bertanya, anak dapat menyelesaikan pekerjaannya sendiri, Anak mampu menggunakan alat bermain sesuai dengan fungsi, Anak dapat menyebutkan berbagai macam perbedaan dan persamaan suatu benda, Anak mampu menjelaskan kegiatan main yang telah dilakukan.

\section{KESIMPULAN}

Upaya dalam mengembangkan manajemen pembelajaran dalam pengembangan kemandirian anak di TK Edelweis Kelurahan Tanjung Pinang kecamatan Jambi Timur Kota Jambi dilakukan dengan melalui perencanaan, pelaksanaan dan evaluasi. Kendala yang di hadapi guru dalam menerapkan manajemen pembelajaran dalam pengembangan kemandirian anak di TK EdelweisKelurahan Tanjung Pinang kecamatan Jambi Timur Kota Jambi adalah Minimnya sarana parasarana pendukung dalam kegiatan pembelajaran online, minimnya pengetahuan orang tua dalam pengasuhan terhadap pertumbuhan serta pekembangan anak, serta kurangnya dukungan orang tua terhadap kemandirian anak sehingga akan merasa tidak percaya diri dalam melakukan kegiatan. Hasil penerapan manajemen pembelajaran dalam pengembangan kemandirian anak di TK EdelweisKelurahan Tanjung Pinang kecamatan Jambi Timur Kota Jambi dapat terlaksana sesuai dengan tujuan pembelajaran yang telah disusun sebelumnya, meski di tengah tengah semester kegiatan pembelajaran berubah menjadi sistem daring atau online dikarena dalam masa pandemi menghadapi Covid-19. 
Siti Marwah : Manajemen Pembelajaran Dalam Mengembangkan Kemandirian |81

\section{REFERENSI}

Agus Wibowo. (2013). Manajemen Pendidikan Karakter di Sekolah. Yogyakarta: Pustaka Belajar.

Aisyah Fitrah. (2018). Meningkatkan Kreatifitas Anak usia Dini Melalui Koran Bekas di TK. Islam Al Falah Kota Jambi,. Jurnal Universitas Jambi.

Amirul Hadidan Haryono. (1998). Metodologi Penelitian Pendidikan. Bandung: Pustaka Setia.

Baharudin dan Moh. Makin. (2010). Manajemen Pendidikan Islam, Transformasi menuju Sekolah Unggul. Malang: UIN Maliki Pers.

B.E.F. Montolalu dkk. (2010). Bermain dan Permainan Anak Modul 1-12. Jakarta: Penerbit Universitas Terbuka.

Engkoswara dan Aan Komariah. (2011). Administrasi Pendidikan. Bandung: Alfabeta.

Jamal Ma'ruf Asmani. (2009). Manajemen Strategis pendidikan Anak Usia Dini. Jogjakarta: Diva Press.

Jurnal, Destriyani Butar Butar. (2018). Peningkatan Kemandirian Anak usia Dini melahi kegiatan Practical Life Pada Kelompok B di TK Islam Al Muttaqin Kota Jambi Tabun 2018. Fakultas Keguruan Dan Ilmu Pendidikan Universitas Jambi.

Luluk Asmawati. (2014). Perencanaan Pembelajaran PAUD. Bandung: Rosdakarya.

Martinis Yamin dan Jamilah Sabri Sanan. (2010). Panduan Pendidikan Anak Usia Dini. Jakarta: Gaung Persada.

Mansur. (2009). Pendidikan Anak usia Dini Dalam Islam. Yogyakarta: Pustaka Belajar.

M. Hgalim Purwanto. (1992). Ilmu Pendidikan Teoritis dan Praktis Cetakan ke-5. Bandung: Rosdakarya.

Mukhtar Latif, dkk. (2013). Orientasi Baru Pendidikan Anak usia Dini dan Aplikasi. Jakarta: kencana Prenada Media Group.

Mursid. (2015). Pengembangan Pembelajaran PAUD. Bandung: PT. Remaja Rosdakarya.

Muhammad Fadhillah. (2012). Desain Pembelajaran PAUD. Tinjauan Teori \& Praktik. Yogyakarta: AR Ruzz Media.

Novi Mulyani. (2018). Perkembangan Dasar Anak Usia Dini. Yogyakarta: Gava Media. 
82 | ZURIAH : Jurnal Pendidikan Anak Usia Dini, Vol. 1 No. 2, 2020

Siti Aisyah, dkk. (2011). Perkembangan dan Konsep Dasar Pengembangan Anak Usia Dini. Jakarta: Universitas Terbuka.

Suryadi dan Mulidya Ulfa. (2013). Hakekat Paud dan Pentingnya Pendidikan Anak usia Dini. Bandung: Remaja Rosdakarya.

Suhar simi Arikunto. (2006). Prosedur Penelitian. Jakarta: Rineka Cipra.

Sugiyono. (2010). MemahamiPenelitianKualitatif. Bandung; CV Alfabeta.

Sugiyono. (2007). MetodePenelitianPendidikan: Pendekataankuantitatif, kualitatifdan R \&D, Bandung: Alfabeta.

Syamsu Yusuf. (2010). Psikologi Perkembangan Anak dan Remaja. Bandung: PT Remaja Rosda Karya.

Trianto Ibnu badar Al-Tabayani. (2011). Desain Pengembangan pembelajaran Tematik Bagi Anak Usia Dini. Jakarta: Premadia Group.

Yuliani Nuraini Sudjiono. (2011). Konsep Dasar Pendidikan Anak Usia Dini. Jakarta: PT Indeks.

Yuliani Nuraini Sudjiono. (2010). Bermain Berbasis Kecerdasan Jamak. Jakarta: PT Indeks, 2010. 